\title{
EXCURSION TO OXFORD, STONESFIELD, AND FAWLER.
}

\author{
Saturday, May 9Th, I908. \\ Director: Prof. W. J. SolLas, Sc.D., LL.D., F.R.S. \\ Excursion Secretary: MARK Wilks. \\ (Rrport by Charles J. Bayzand.)
}

THE party left Paddington at $9.5^{\circ}$ a.m. and alighted at Oxford, where they were joined by a contingent from the neighbouring Midlands, and met by Prof. Sollas. The party, numbering 35, travelled by brake and bicycle along the Woodstock Road to Summertown, lying to the north of Oxford, where the first halt was made at Mr. Webb's Brick Pit.

Here beneath $8 \mathrm{ft}$. of valley gravel-the Second Terrace Gravel-the Oxford Clay is worked to a depth of $40 \mathrm{ft}$. It is of a bluish-grey colour, and is slightly calcareous. The exposure

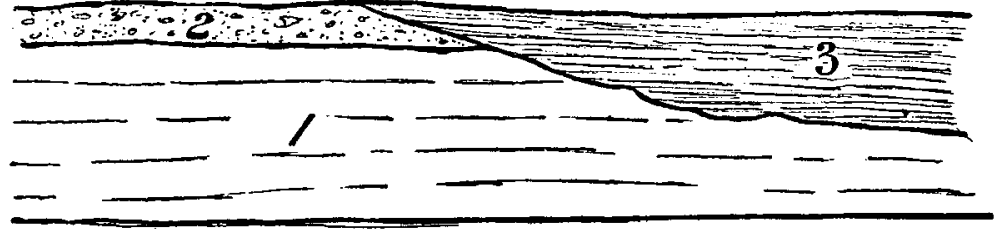

Fig. 6.-Section of Wolvercote Brick Pit.-C. F. B.

3. Fine laminated sandy loam and clay.

2. Unstratified Gravel with Quartzite Pebbles and Flints.

I. Oxford Clay.

is in the zone of Cosmoceras ornatum, and the sub-zone of Cosmoceras jason. Numerous fossils were found by the party, including: Cosmoceras ornatum, C. jason, C. duncani, Peltoceras annulare, Perisphinctes matheyi, P. leaionicum, Belemnites sulcatus, B. hastatus, Nucula ornatus, Pecten fibrosus, Gryphcea dilatata, $G$. bilobata, Avicula inaquivalvis, Rhychonella varians, Aulacothyris impressa, Anabacia complanata, and many others.

In addition, a new, or very lately known, Gasteropod was found by one of the party, Mr. C. F. C. Beeson, and is now placed in the Oxford Museum.

Leaving Summertown and proceeding along the Woodstock Road a gradual ascent was made to Wolvercote. Here a visit was paid to Messrs. T. H. Kingerlee's Brick Works. At the top of the clay in this pit are to be seen Gravels of the Third 
Terrace in which fine examples of early Palæolithic or Chelléen implements have been found.

With these gravels were a series of fine laminated sandy loam and clays, which were probably laid down in a hollow eroded through the gravel into the Oxford Clay (which occurs beneath). The surface of the clay showed disturbances, which have been attributed to the passage of ice. At the base of the sandy loam and clay, bands of gravel were seen.

The clay in this pit is exposed to a depth of about $40 \mathrm{ft}$., and is in every way similar to that at Summertown. Fossils were again numerous. In addition to those already mentioned, Peltoceras athleta, Belemnites oweni, and Quenstedtictras maria were obtained by members of the party.

Proceeding still along the Woodstock Road the exposure of

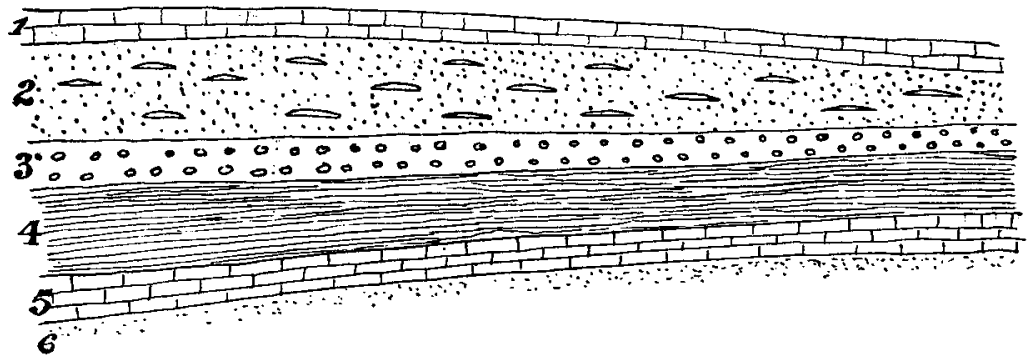

Fig. 7.-Section of Fawler Quarry.-C. $\mathcal{F} . B$.

I. White Oolite.

2. Clypeus Grit. Inferior

3. Upper Trigonia Grit $\}$ Oolite.

4. Upper Lias Clays.

5. Middle Lias Marlstone.

6. Marlstone Sands.

Oxford Clay in the Pear Tree Hill Brickyard was passed but was not visited.

On the way to Bladon the junction of the Cornbrash and the Oxford Clay was traversed near to Begbroke.

The next halt occurred at Bladon, which lies to the left of the road before reaching Woodstock.

The following section was explained :

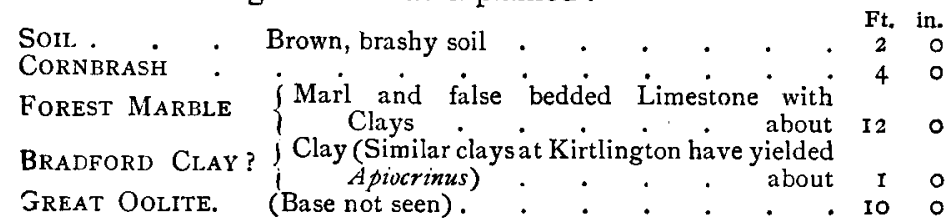

Fossils found: Cornerash, Terebratula obovata, Myacites cuneiforme, Avicula echinata; Forest MARBLE, Acrosalenia hemicidaroides, Modiola sozerbyana, Ostrea sowerbyi, Lima cardiiformis, and others. 
Proceeding to Hanborough the gravel pits there were visited. These belong to the $4^{\text {th }}$ Terrace Gravels. At the top occurs a layer of brown loam of irregular thickness, containing quartzite pebbles, and descending in pipes to the bottom of the pit. This was explained very fully by the Director and greatly interested the party.

Proceeding along the road to Stonesfield a section near Hanborough Station was seen by some members of the party en passant. The section was in every way similar to Bladon.

At Stonesfield the party were able to collect specimens of the famous Stonesfield Slates, which are still being worked on a small scale and afford numerous fossils. The first example of the earliest known mammalian jaws was found in this locality by Mr. J. Platt in $\mathbf{7} 734$.

The Stonesfield Beds, at Stonesfield, which occur at the base of the Great Oolite at a depth of $18 \mathrm{ft}$, consist of beds 5 ft. 3 in. in thickness, viz., thin band of yellowish sandy clay, sphæroidal concretions of calcareous grit ("Pot-lids") with oolitic particles, slaty, friable sand. rock (which yields the greater number of fossils, including Mammalian remains, Trigonia impressa, etc.), and coarser Calcarerous Grit.

The Stonesfield "Slates" Beds are got at by means of a shaft sunk through the Great Oolite. Many of the members took the opportunity of inspecting the bed in its stratigraphical position.

The Slate Bed itself is brought to the surface up the shaft in

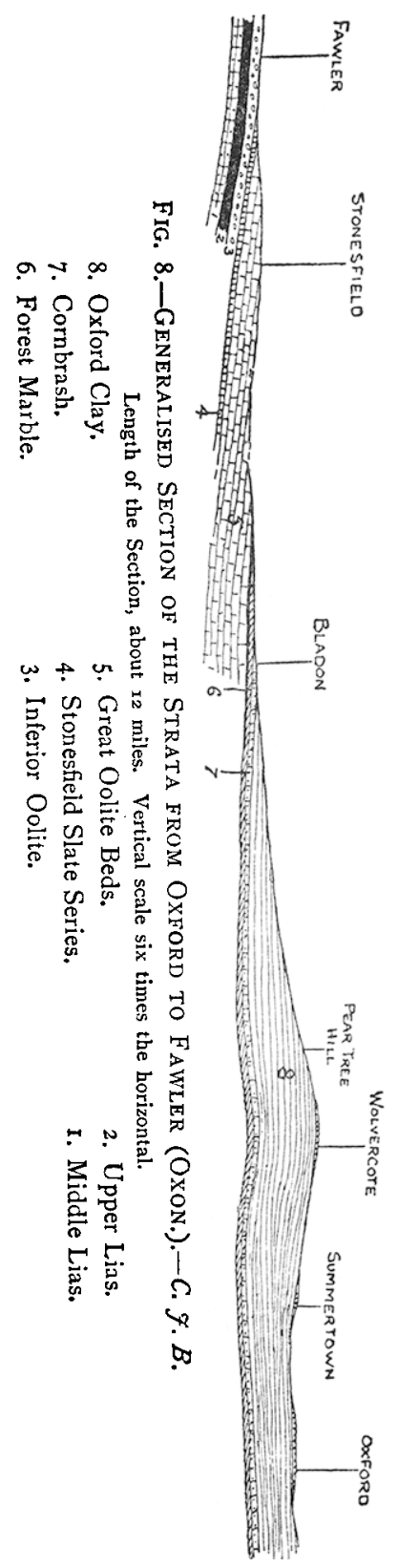


large blocks, and is allowed to stand and weather during the winter, when in the spring it easily breaks up into thin sheets or "slates."

Many fossils were obtained from the workmen and also from the spoil heaps, including: Trigonia impressa, $T$. moretoni, Gervillea acuta, Lima cardiiformis, L. pecteniformis, Modiola imbricata, Ostrea sowerbyii, Pecten annulatus, P. lens, Rhynchonella obsoleta, $R$. concinna, and others.

From Stonesfield we proceeded to Fawler to see the section of the Inferior Oolite, which had the day previously been cleared to show the junction of Clypeus Grit and Upper Trigonia Grit resting directly on the Upper Lias Clay, which is extremely attenuated, so that a section extending from the Middle Lias Marlstone to the Inferior Oolite is exposed within a distance of 30 feet.

Numerous fossils were found: Inferior Oolite-Parkinsonia parkinsoni, Clypeus plotti, Echinobrissus clunicularis, Pinna sp., Homomya gibbosa, Lima gibbosa, Pholadomya deltoidea, P. lyrata, Terebratula submaxillata, Terebratula globata, Rhynchonella obsoleta, Acanthothyris spinosa, Anabacia orbitolites.

Upper Lias-Harboceras serpentinum, Dactylioceras commune, D. holandrei, Hildoceras bifrons, Belemnites sp.

Middle Lias-Terebratula punctata, Rhynchonella tetrahedra, and others.

Briefly summarising, the party had been enabled, under the guidance of the Director, to see, in a distance of about twelve miles from Oxford, a series of excellent sections, representing the following stratigraphical horizons :

The four Terrace Gravels (the first Terrace occurs at Oxford).

Middele Oolites. Oxford Clay.

LOWER OOLITES $\left\{\begin{array}{l}\text { Cornbrash. } \\ \text { Forest Marble. } \\ \text { Bradford Clay (?) } \\ \text { Great Oolite. } \\ \text { Stonesfield Slate. } \\ \text { Inferior Oolite. }\end{array}\right.$

UPPER LIAS.

MIDDLE LIAS.

The party then proceeded to the Bell Hotel, Charlbury, where tea was awaiting them.

After tea a vote of thanks to the Director was proposed and carried unanimously.

The Members returned to London by the 6.40 p.m. train from Charlbury.

\section{REFERENCES.}

1871. PHILlips.- "Geology of Oxford and the Valley of the Thames."

I886. BATHER, F. A.- "Recent Openings at Fawler." Quart. Fourn. Geol. Soc., vol. xlii, pp. 143-146.

1894. Britlsh Association Report :" Oxford. Stonesfield Slate," pp. 304-306. 
I895. British Association Report: "Ipswich. Stonesfield Slate," pp. 414-4I5.

1896. British Association Report : "Liverpool. Stonesfield Slate," p. 356.

1904. BELL, A. MONTGOMERIE. - "Implementiferous Sections at Wolvercote." Quart. Fourn. Geol. Soc., vol. lx, pp. I20-1 32.

1908. Survey Memoir and Map, "The Geology of the Country around Oxford," by T. I. Pocock, M.A., with contributions by H. W. Woodward and G. W. Lamplugh.

EXCURSION TO SWANSCOMBE AND GALLEY HILL.

\author{
Saturday, MAY 23RD, 1908. \\ Director: James Cross, F.G.S. \\ Excursion Secretary: Miss M. S. Johnston.
}

(Report by Miss M. S. Johnston.)

THE party, which numbered forty-five, left Cannon Street Station at 1 2.57. On arriving at Northfleet the Director led the party across the line to Baker's Hole Chalk pit, where several implements were found. After passing a remarkable section of denuded chalk, overlaid by later beds, the Members ascended the hill amongst the sand-pits, where their attention was drawn to examples of hill-creep and slickensides in the sands and clays (possibly Thanet Beds). Swanscombe Hill was next ascended by Watling Street, and the old earth-works were examined. Quantities of small flakes were picked up in the fields on the way back to tea at the Milton Street Arms. After tea the Members visited the Milton Street Gravel Pits, where the Director had provided men to dig the gravel in the hope of finding Palæolithic flint implements, but nothing of importance was found on this occasion. Dearden's Gravel pit was next visited, and a roadside section at Swanscombe, where a profusion of Pleistocene shells was found, Neritina being especially abundant. The colour ornamentation of the shell is well preserved. At Galley Hill Mr. R. Elliot pointed out the place where he found the "Galley Hill skull," about which there has been so much discussion. This being the completion of the day's work the President proposed a vote of thanks to the Director, and also expressed his pleasure at the presence of Mr. Elliot. Most of the party returned from Northfleet by the 8.40 train, but a few stayed on to partake of the hospitality of the Associated Portland Cement Manufacturers, Limited, on whose property many of the 